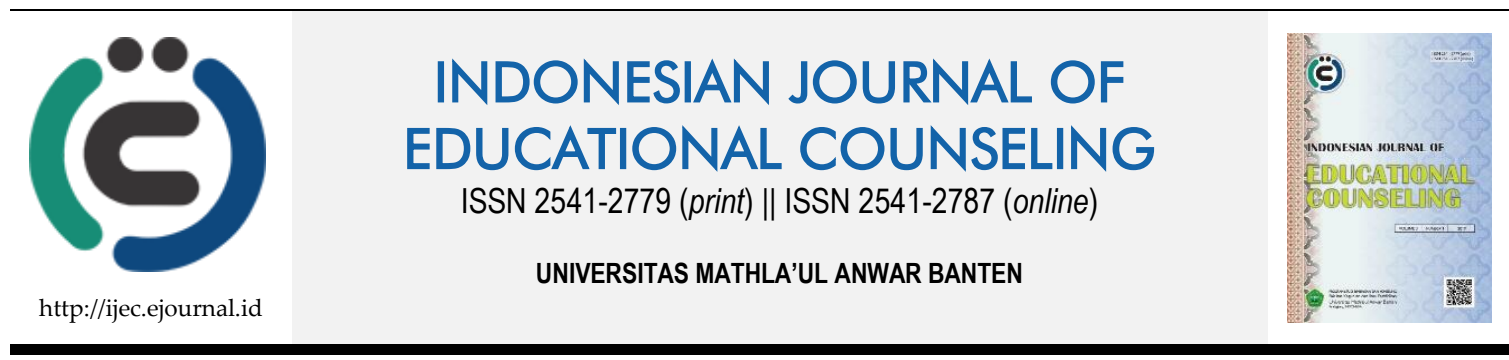

Theoretical/Conceptual Article

\title{
Pendekatan Eksistensial dalam Praktik Bimbingan dan Konseling
}

\author{
Uray Herlina ${ }^{1}$, Ade Hidayat ${ }^{2}$
}

${ }^{1}$ IKIP PGRI Pontianak, 2 Universitas Mathla'ul Anwar Banten

\begin{tabular}{|c|c|}
\hline Article History & ABSTRACT \\
\hline $\begin{array}{l}\text { Received: } 19.07 .2018 \\
\text { Received in revised form: } \\
21.11 .2018 \\
\text { Accepted: } 04.01 .2019 \\
\text { Available online: } 23.01 .2019\end{array}$ & $\begin{array}{l}\text { Existentialism could not be detached from Soren Kierkegaard's idea, Nietzche's, Karl } \\
\text { Jaspers's, then was developed by Martin Heidegger and Jean Paul Sarte who made } \\
\text { existentialism become more outstanding. In psychology and Counseling, } \\
\text { Existentialism approach get many influences from Kierkegaard opinion that opposes } \\
\text { every efforts that view human being as an object, simultaneously opposes the } \\
\text { subjective perception as only one human reality. Kierkegaard and many further } \\
\text { existentialists, emphasize balancing between free-will and responsibility. Guidance } \\
\text { and Counseling with existentialism approach appreciate democratic principle, } \\
\text { emphasize dialog process, because freedom is one of choices. Based on this principle, } \\
\text { every counselor has responsibility about value system which adopted by their } \\
\text { counselee as long as it is not against with moral principle. Every counselor are } \\
\text { demanded to behave ethically and rationally, and build value deeply and push their } \\
\text { counselee to be responsible with their choice. }\end{array}$ \\
\hline
\end{tabular}

Keywords: Dialogue, Existentialism, Guidance and Counseling.

DOI: 10.30653/001.201931.80

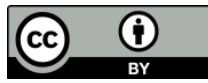

This is an open access article distributed under the terms of the Creative Commons Attribution 4.0 International License, which permits unrestricted use, distribution, and reproduction in any medium, provided the original work is properly cited. ๑) 2019 Uray Herlina, Ade Hidayat.

\section{PENDAHULUAN}

Pembahasan mengenai eksistensialisme tidak dapat dilepaskan dari pemikiran Soren Kierkegaard, Nietzche, dan Karl Jaspers, kemudian dikembangkan oleh Martin Heidegger dan Jean Paul Sartre yang membuat eksistensialisme semakin terkenal. Soren Kierkegaard (1813-1855) seorang filsuf Denmark yang dikenal sebagai bapaknya filsafat eksistensialisme, dalam pemikirannya ingin menjawab pertanyaan: Bagaimanakah aku menjadi seorang diri? Kierkegaard berusaha untuk menemukan jawaban untuk pertanyaan tersebut bahwa manusia (aku) bisa menjadi individu yang otentik jika memiliki gairah, keterlibatan, dan komitmen pribadi dalam kehidupan.

Eksistensialisme adalah suatu reaksi terhadap materialisme dan idealisme. Eksistensialime menolak pendapat materialisme terhadap manusia sebagai benda dunia, manusia adalah materi, manusia adalah sesuatu yang ada tanpa menjadi subyek. 
Demikian pula pandangan manusia menurut idealisme: manusia hanya sebagai subyek atau hanya sebagai suatu kesadaran, itu ditentang oleh eksistensialisme.

Eksistensialisme menekankan keunikan dan kedudukan pertama eksistensi, pengalaman kesadaran yang dalam dan langsung. Desakan yang pokok atau pendorong adalah untuk hidup dan untuk diakui sebagai individual. Jika seorang manusia diakui seperti itu, ia akan memperoleh arti dan makna dalam kehidupan. Tempat bertanya yang paling penting bagi seorang manusia adalah kesadarannya yang langsung, dan kesadaran itu tidak terkandung dalam sistem atau abstraksi.

Namun, menjadi eksistensialis, bukan melulu harus menjadi seorang yang bedadaripada-yang-lain, sadar bahwa keberadaan dunia merupakan sesuatu yang berada di luar kendali manusia, tetapi bukan membuat sesuatu yang unik ataupun yang baru yang menjadi esensi dari eksistensialisme. Membuat sebuah pilihan atas dasar keinginan sendiri, dan sadar akan tanggung jawabnya pada masa depan adalah inti dari eksistensialisme. Sebagai contoh, manusia dalam kehidupannya akan terjun ke berbagai profesi seperti dokter, desainer, insinyur, pebisnis dan sebagainya, tetapi yang dipersoalkan oleh eksistensialisme adalah, apakah seseorang menjadi dokter atas keinginan orang tua, atau keinginan sendiri. Secara filosofis, eksistensialisme memandu agar manusia menjadi dirinya sendiri, mengalami individualitasnya. Eksistensi berarti berdiri sendiri sebagai diri sendiri, dalam bahasa Heidegger (1996, p. 5), manusia sadar dengan tempatnya (Dasein).

\section{KAJIAN LITERATUR}

Pendekatan eksistensial dalam bidang psikologi dan konseling mendapat banyak pengaruh dari pendapat Kierkegaard yang menentang upaya apa pun untuk melihat manusia hanya sebagai objek, namun pada waktu bersamaan dia juga menentang bahwa persepsi subjektif hanya satu-satunya realitas manusia. Kierkegaard, juga para eksistensialis berikutnya, menekankan keseimbangan antara kebebasan dan tanggung jawab. Akan tetapi Kierkegaard hanya memberikan kontribusi sedikit terhadap pemikiran filsafat pada saat itu. Kemudian filsafat ini dilanjutkan oleh Friedrich Nietzshe (1844-1900) dan Martin Heidegger (1899-1976) sehingga eksistensialisme menjadi populer. Heidegger sangat mempengaruhi Binswanger dan Medard Boss yang kemudian bersama Karl Jaspers, Frankl dan lain-lain, mengadaptasi filsafat ini ke dalam praktik psikoterapi.

Awal kemunculan pendekatan eksistensial dalam psikologi dan konseling dapat dikatakan sebagai reaksi ketidakpuasan beberapa psikiater dan psikolog terhadap beberapa teori dan praktik psikoanalisis di Eropa Barat dan behaviorisme di Amerika Serikat, maka pendekatan eksistensial dapat disebut sebagai mazhab ketiga dalam konseling dan psikoterapi. Model eksistensial tumbuh dan berkembang sebagai reaksi melawan psikoanalisis dan behaviorisme yang dianggap tidak berlaku adil dalam mempelajari manusia.

Pertama dan sangat penting, psikologi eksistensial menentang penggunaan konsep kausalitas dalam ilmu-ilmu eksakta untuk menilai perilaku atau kepribadian. Menurut konsep ini tidak ada hubungan sebab-akibat dalam keberadaan manusia. Paling hanya dikatakan ada rangkaian tingkah laku, tetapi tidak bisa kausalitas diturunkan dalam rangkaian tersebut. Karena menolak kausalitas, maka eksistensial menolak juga positivisme, determinisme, dan materialisme. Psikologi eksistensial memiliki metode sendiri, yakni fenomenologi dengan konsep-konsep, seperti ada-di-dunia (being-in-theworld), cara-cara keberadaan, kebebasan, tanggung jawab, menjadi, transendensi, intensionalitas, dan hal-hal lain yang banyak diadopsi dari ontologi Heidegger. 
Psikologi eksistensial mengganti konsep kausalitas dengan konsep dorongan. Medard Boss menggunakan contoh jendela yang ditutup oleh angin dan oleh manusia untuk menjelaskan perbedaan antara sebab dan dorongan. Angin menyebabkan jendela tertutup, tetapi orang terdorong untuk menutup jendela karena dengan ditutupnya jendela, maka angin, hujan, maupun suara bising di luar bisa diredam atau tidak bisa masuk. Benar bahwa tangan orang menekan jendela yang menyebabkan jendela tertutup, tetapi tindak menekan itu sendiri memerlukan pemahaman di mana tangan orang itu diletakkan, apakah mendorong, menarik sesuatu atau hal lainnya. Maka, kausalitas kurang atau tidak relevan dengan tingkah laku manusia. Dorongan dan pemahaman merupakan prinsip-prinsip operatif dalam analisis eksistensial tingkah laku.

Kedua, kaum eksistensial menentang dualisme. Ini erat kaitannnya dengan keberatan pertama di atas. Dualisme antara subjek (pikiran) dan objek (badan, lingkungan, atau benda) ditentang oleh eksistensial. Tidak seperti Descartes yang menjelaskan pengalaman dan tingkah laku manusia berkenaan dengan dorongandorongan lingkungan dan keadaan-keadaan jasmani/biologis. Psikologi eksistensial mempertahankan kesatuan individu-dalam-dunia, dengan menyebut setiap pandangan yang merusak kesatuan ini berarti memecahkan dan memalsukan keberadaan manusia.

Ketiga, psikologi eksistensial juga tidak menerima bahwa ada sesuatu di balik gejalagejala yang menjelaskan atau menyebabkan gejala-gejala tersebut nampak. Bagi eksistensial, gejala-gejala adalah hal-hal yang ditangkap langsung, bukan merupakan tampang luar atau derivasi dari sesuatu yang lain. Psikologi eksistensial merupakan usaha psikologi untuk menjelaskan gejala-gejala sedetail dan selengkap mungkin berdasarkan penjelassan fenomenologis, bukan penjelasan atau bukti kausal.

Berdasarkan penjelasan tentang penentangan eksistensial terhadap konsep psikoanalisis dan behaviorisme di atas, dapat dirumuskan konsep dasar penting yang dikembangkan dan menjadi khas eksistensialisme di tengah pengertian beragam berdasarkan pendapat para tokohnya. Konsep dasar ini umum digunakan juga dalam pendekatan konseling dan psikoterapi eksistensial, yakni: (1) ada dan non-ada; (2) ada-didunia; (3) relasi Aku-Kamu; (4) intensionalitas; dan (5) keberadaan otentik dan keberadaan tidak otentik.

\section{Ada dan Non-ada}

Ada ialah ukuran bagi keberadaan manusia, suatu dimensi yang mengacu kepada kesubjekan (subjectness) manusia. Dengan mengada, manusia hadir dan menampakkan diri, mengalami dirinya sebagai subjek yang sadar, aktif dan berproses. Sedangkan nonada adalah ukuran bagi ketiadaan manusia, suatu dimensi yang mengacu kepada keobjekan (objectness) dari manusia. Dalam non-ada, manusia melakukan negasi atas keberadaannya, dan mengalami dirinya sebagai objek (Sartre, 1978, p. 9). Lebih jauh Sartre menegaskan bahwa ada dan non-ada adalah dua dimensi yang saling bergantung dalam memberi nuansa yang tegas pada keberadaan manusia, ibarat gambar dengan latar belakangnya yang membentuk sebuah lukisan. Sebuah lukisan menjadi jelas dan memiliki nuansa karena gambar (figure) yang terdapat di dalamnya ditopang oleh latar belakang (ground). Demikian pula dengan keberadaan manusia yang memiliki nuansa yang tegas karena pada dirinya terangkum ada dan non-ada sekaligus. Artinya, manusia menghayati keberadaan (sense of being) karena ia mengintegrasikan ada dan non-ada.

\section{Ada-di-Dunia}

Eksistensialisme diawali oleh Kierkegaard menentang segala usaha untuk melihat manusia hanya sebagai objek, dan pada saat bersamaan menentang pandangan bahwa persepsi subjektif adalah satu-satunya realitas yang dimiliki seseorang. Kierkegaard 
berusaha untuk mengatasi dikotomi dari rasionalitas dan emosi dengan mengarahkan perhatian manusia pada kenyataan atas pengalaman yang baru saja dialami.

Konsep ada-di-dunia (bahasa lnggris: being-in-the-world, bahasa Jerman: in-der-weltsein, bahasa Prancis: l,etre-dans-lemonde) diperkenalkan oleh Martin Heidegger artinya manusia hidup atau mengungkapkan keberadaannya dengan mengada di dalam dunia. Dalam istilah Heidegger manusia harus sadar dengan lingkungannya, sadar dengan Dasein-nya, artinya hadir dan bereksistensi di dunia (being-in-the-world). Tanda hubung dalam istilah tersebut digunakan untuk mengimplikasikan kesatuan subjek dan objek, manusia dan dunia. Dalam pengertian Binswanger (1963), manusia mengalami tiga bentuk being-in-the-world yang terjadi secara bersamaan: Umwelt, hubungan individu dengan lingkungan; Mitwelt, hubungan individu dengan orang lain; Eigenwelt, hubungan individu dengan diri sendiri. Sementara ada tambahan dimensi lain dari van DeurzenSmith (2002, p. 62), yakni Uberwelt, hubungan individu dengan dimensi spriritual (transendental).

\section{Relasi Aku-Kamu}

Martin Buber (1970) mengembangkan konsep relasi Aku-Kamu (I-Thou relationship) untuk menggambarkan relasi antar pribadi yang sungguh-sungguh atau sejati, yang kontras dengan satu bentuk relasi yang disebut I-it relationship. Di dalam relasi AkuKamu, individu sadar dan menghargai partner relasinya sebagai subjek seperti dirinya, subjek dengan dunianya sendiri, subjek yang selalu berproses, dan subjek yang memiliki perasaan, pikiran, dan keinginannya sendiri. Sikap individu semacam ini memungkinkan individu tersebut memiliki kesediaan untuk memberikan empati kepada rekan (partner) relasinya, yang pada gilirannya menjadikan individu sanggup mencoba membayangkan apa dan bagaimana dunia yang nampak dan perspektif subjektif rekan relasinya itu.

Berbeda dengan relasi Aku-kamu, dalam relasi yang disebut I-it relationship individu melihat partner relasinya bukan sebagai subjek, melainkan sebagai objek; suatu objek yang bisa diabaikan maupun digunakan untuk kepentingan pribadi si individu. Jadi, dalam relasi semacam ini tidak terdapat kesediaan untuk memberikan empati kepada partner relasi dan, karenanya, tidak ada kesanggupan pada individu untuk memahami dunia partner relasinya. Jika I-it relationship ini diberlakukan dalam psikoterapi, maka berarti terapis memperlakukan klien sebagai objek penerima perlakuan (treatment) dan sebagai objek yang perbaikan atau kesembuhannya merupakan fungsi dan keefektifan terapis dengan perlakuan yang diberikannya itu. Relasi terapeutik yang demikian ditentang oleh para terapis eksistensial.

\section{Intensionalitas}

Intensionalitas adalah konsep eksistensialisme yang mirip dengan prinsip determinisme psikis dari psikoanalisis, yang mengemukakan bahwa kejadian-kejadian mental tidak muncul secara kebetulan. Dalam arah yang sama tetapi dengan penekanan yang berbeda, konsep intensionalitas diambil dari pemikiran Brentano dan Hussert yang menyebutkan bahwa kesadaran manusia selalu memiliki maksud atau terarah kepada sesuatu. Rollo May (1958) menegaskan bahwa kesadaran ditentukan oleh fakta bahwa kesadaran itu selalu mengarah kepada suatu objek. Suatu tindakan bisa disebut intensional apabila tindakan itu dilakukan dengan tujuan yang jelas dan kesadaran penuh.

Para eksistensialis juga menggunakan konsep intensionalitas untuk menerangkan persepsi. Mereka menekankan bahwa persepsi itu menuntut adanya kesediaan individu untuk melibatkan diri ke dalam aspek realitas tertentu yang (akan) dipersepsinya. Dengan perkataan lain, tindakan mempersepsi menuntut adanya intensi dari individu terhadap 
sesuatu yang akan dipersepsinya. Sebaliknya, jika individu tidak memiliki intensi (tidak memiliki maksud atau niat) kepada sesuatu, maka dia tidak akan mempersepsi sesuatu itu. Hal ini dapat dicontohkan dengan orang yang melamun atau orang yang konsentrasinya pada tempat lain. Sekalipun adanya stimulus (sinar, gelombang cahaya atau lainnya) ke dalam inderanya (mata, telinga, dll), dan secara fisik, kecepatan, panjang gelombang, kerasnya dan lain-lain mencukupi untuk melihat, mendengar dan seterusnya, tetapi apabila manusia itu tidak berkehendak untuk mempersepsi itu (melamun atau membayangkan, atau memikirkan yang lain), maka ia tidak melihat dan mendengar. Contoh; banyak orang yang dipanggil tetapi tidak dengar atau merasa dipanggil padahal panggilannya jelas dan keras.

Berdasarkan contoh di atas, muncul keyakinan para eksistensialis bahwa apa dan bagaimana persepsi individu terhadap suatu hal sedikit banyak dipengaruhi oleh intensinya terhadap hal tersebut. Keyakinan para eksistensialis ini didukung oleh sejumlah penelitian, seperti ditunjukkan Allport yang menunjukkan bahwa persepsi dipengaruhi oleh harapan-harapan, anggapan-anggapan, dan kecenderungan merespons (set) yang ada pada diri individu.

\section{Keberadaan Otentik dan Keberadaan Tidak Otentik}

Konsep keberadaan otentik (authentic existence) dan keberadaan tidak otentik (inauthentic existence) juga merupakan konsep yang fundamental bagi para eksistensialis dan para ahli psikologi eksistensial. Keberadaan yang tidak otentik adalah keberadaan individu yang mengukuhkan dirinya dengan cara atau untuk tujuan menghindarkan diri dari wujud-wujud non-ada, yakni keniscayaan-keniscayaan hidup yang terdiri atas kematian, keharusan memilih dan memikul tanggung jawab, isolasi dan ketidakbermaknaan. Ia tidak berani untuk mengambil hidup dengan segala keterbatasannya, penderitaan, kematian, tanggung jawab dan lain-lain. Ia mengukuhkan dirinya bukan untuk dirinya. Ia mencari sukses lewat status, dan sukses menurutnya adalah adanya tepuk tangan penonton. Ia selalu melihat penopangan dari orang lain sebagai bagian pengukuhan dirinya (self affirmation). Keberadaan ini tidak utuh dan rapuh.

Sebaliknya, dalam keberadaan yang otentik, individu sanggup mengukuhkan dirinya tanpa mengingkari keniscayaan-keniscayaan hidup (tidak mengingkari bahwa dirinya akan mati, bahwa dirinya harus membuat pilihan-pilihan atau putusan-putusan yang vital bagi hidupnya, bahwa dirinya bisa mengalami isolasi dari sesama dan mengalami ketidakbermaknaan), juga tanpa mengikat orang lain dan tidak menggantungkan diri pada orang lain. Keberadaan otentik merupakan gambaran ideal bagi para eksistensialis dan terapi eksistensial.

Untuk mewujudkan keberadaan diri yang otentik, maka kebebasan mutlak diperoleh manusia. Pendapat ini bersumber dari pemikiran Sartre yang dengan lantang menyerukan kebebasan manusia. Manusia itu bebas dan tidak terdeterminasi oleh masa lampau, karena eksistensi manusia mendahului esensinya, jadi manusia tidak mengembangkan dirinya berdasarkan esensi yang sudah ditentukan. Eksistensi pada esensialnya menunjukkan kepada kesadaran manusia (l'etre-pour-soi). Dalam kata-kata Sartre (1948: 28), "Man is nothing else but that which he makes of himself". Inilah asas paling esensial dalam filsafat eksistensialisme, yang disebut oleh Sartre sebagai subjektivitas.

Asumsi dasar Sartre tersebut dikembangkan oleh Binswanger bahwa esensi manusia adalah kebebasan manusia. Di mana hal yang ada pada tiap diri manusia membedakan kita dari apapun yang ada di alam semesta ini. Kita sebagai manusia masing-masing telah 
memiliki "modal" yang beraneka ragam, namun tetap memiliki kesamaan tugas untuk membentuk diri kita sendiri (Binswanger, 1966).

Manusia tidak mengembangkan eksistensinya sesuai dengan esensinya yang sudah terpatok, tidak seperti benda yang dibuat tukang. Ketika seorang tukang membuat kursi, esensi kursi sudah ditentukan sehingga tukang hanya membuat kursi berdasarkan model kursi yang sudah dirancang. Tidak demikian halnya dengan manusia. Manusia membangun eksistensinya dulu baru esensinya muncul. Artinya dia tidak bisa ditentukan, melainkan menentukan, dia adalah aktor bukan pengekor yang selalu diarahkan pada satu pola yang sudah ditentukan.

Eksistensialisme berasumsi bahwa manusia, merupakan makhluk yang tidak bisa disubordinasikan atau direduksikan pada angka-angka (statistik) dan pengukuran fisikmekanistik (biologi) saja, karena dalam dirinya terkandung makna atau nilai personal yang tidak bisa dikuantifikasi dan tidak bisa dijelaskan secara biologi saja. Eksistensialisme mengacu pada dua disiplin yang berbeda, tetapi satu sama lain saling berhubungan, yakni pada (1) penerapan metode fenomenologi untuk menjelaskan eksistensi manusia dan (2) aplikasi fenomenologis dan temuan-temuan eksistensialisme dalam terapi-terapi psikologis dan psikiatris. Temuan-temuan eksistensialisme mengenai eksistensi dan pengalaman manusia menjadi acuan yang sangat berharga terutama untuk terapi psikologis dan psikiatri, di samping untuk penelitian-penelitian eksistensial, banyak temuan para eksistensialis yang dijadikan sebagai landasan untuk terapi dan penelitian eksistensial.

Kontribusi pendekatan eksistensial dalam psikoterapi juga menganalisis mengenai hubungan manusia dengan manusia lain (Mitwelt), penyesuaian diri (Umwelt), kesadarandiri, perhubungan diri, secara khas hadir dalam diri manusia (Eigenwelt), serta kebermaknaan diri dalam dimensi spiritual (Uberwelt). Manusia hidup dalam Mitwelt, Umwelt, dan Eigenwelt, juga Uberwelt secara simultan. Yang mana keempatnya merupakan cara manusia hidup dalam dunia.

Eksistensialisme lahir saat manusia pada zaman modern kebingungan mencari sejumlah makna dalam hidup. Saat manusia kehilangan tujuan atau target, maka manusia menjadi sakit, dan mulai terlibat dalam bermacam perilaku yang dapat merugikan bahkan menghancurkan diri sendiri. Banyak orang dalam masyarakat modern, merasa terasing dari dunia (Umwelt), dari orang lain (Mitwelt), dan terutama dari dirinya sendiri (Eigenwelt), serta kering spiritual (Uberwelt).

\section{DISKUSI}

Eksistensialisme sebagai filsafat sangat menekankan individualitas dan pemenuhan diri secara pribadi. Setiap individu dipandang sebagai makhluk unik, dan secara khas pula ia bertanggung jawab terhadap jalan kehidupannya sendiri. Dalam hubungannya dengan pendidikan, Sikun Pribadi (dalam Sadulloh, 2003) mengemukakan bahwa eksistensialisme berhubungan erat sekali dengan pendidikan, karena keduanya bersinggungan satu dengan yang lainnya pada masalah-masalah yang sama, yaitu manusia, hidup, hubungan antar manusia, hakikat kepribadian, dan kebebasan.

\section{Implikasi Pedagogis}

Tujuan pendidikan adalah untuk mendorong setiap individu agar mampu mengembangkan semua potensinya untuk pemenuhan diri. Setiap individu memiliki kebutuhan dan perhatian yang spesifik berkaitan dengan pemenuhan dirinya, sehingga dalam proses belajar mengajar, guru harus memberikan kebebasan kepada siswa memilih 
dan memberi mereka pengalaman-pengalaman yang akan membantu siswa menemukan makna dari kehidupannya. Menggunakan prinsip dialog, guru menyatakan tentang ideide yang dimiliki siswa, dan mengajukan ide-ide lain, kemudian membimbing siswa untuk memilih alternatif-alternatif.

Kaum eksistensialisme berpandangan tidak ada kurikulum yang pasti dan ditentukan berlaku secara umum. Kurikulum dinilai berdasarkan pada sejauh kontribusinya pada pencarian individu akan makna yang muncul dalam suatu tingkatan kepekaaan personal. Kurikulum ideal adalah kurikulum yang memberikan para siswa kebebasan individual yang luas dan mensyaratkan mereka untuk mengajukan pertanyaan-pertanyaan, melaksanakan pencarian-pencarian, sekaligus menarik kesimpulan-kesimpulan mereka sendiri. Menurut pandangan eksistensialisme, tidak ada satu mata pelajaran tertentu yang lebih penting dan lebih tinggi derajat daripada yang lainnya. Mata pelajaran merupakan materi dimana individu akan dapat menemukan dirinya dan kesadaran akan dunianya, bisa berupa pelajaran sosial, pengetahuan alam, hukum, sejarah, sastra, filsafat, seni, dan sebagainya. Melalui berbagai mata pelajaran tersebut, dengan difasilitasi guru dengan proses dialog yang baik, siswa akan berkenalan dengan pandangan dan wawasan para tokoh, memahami hakikat manusia, memahami kebenaran dan kesalahan, kekuasaaan, konflik, penderitaan, dan kematian. Kesemuanya itu merupakan tema-tema yang akan melibatkan siswa baik intelektual maupun emosional.

\section{Relevansi dalam Layanan Bimbingan dan Konseling}

Blocher (1974) menjelaskan, karakteristik filosofis eksistensialisme memandang manusia lebih humanis, individu memiliki kesadaran dan kebebasan, memandang realitas secara subyektif dan berkonotasi religius. Karakteristik filosofis eksistensialisme memunculkan kekhasan dalam proses konseling, yaitu menekankan pada konsep identitas individu dan respon-respon empatik dari konselor.

Pandangan Heidegger bahwa manusia harus sadar dengan lingkungannya, sadar dengan Dasein-nya, artinya hadir dan bereksistensi di dunia (being-in-the-world). Hal tersebut menjadi dasar bagi ilmu konseling dan psikoterapi seperti ditegaskan oleh Rollo May (dalam Corey, 2011) bahwa tugas terapis/konselor adalah membantu klien agar menyadari keberadaannya dalam dunia. Orientasi pandangan ini mengilhami kemunculan pengembangan konseling pada pendekatan ekologis sebagaimana yang dikembangkan Blocher. Pendekatan ekologis merupakan dampak dari upaya mengeksplorasi aspek-aspek di luar individu, yakni lingkungan dan sumber daya. Hal ini mendorong layanan bimbingan dan konseling tertuju kepada upaya membangun lingkungan perkembangan manusia (ecology of human development) yang sehat dalam rangka pengembangan perilaku individu untuk mewujudkan keberfungsian diri dalam lingkungan, membantu individu berkembang secara efektif (Kartadinata, 2011).

Konseling dengan menggunakan pendekatan eksistensial tidak mengarahkan, membimbing, atau menilai konseli berdasarkan praduga-praduga. Tugas konselor hanyalah membantu konseli menjadi dirinya yang otentik. Inti terapi eksistensial adalah hubungan antara konselor dan konseli, yang disebut pertemuan/perjumpaan. Sebuah pertemuan antar manusia yang membahas pengalaman, bukan berkutat pada masalah konseli. Fokus pertemuan membahas pengalaman hubungan konseli dengan orang lain dalam kehadiran yang otentik difokuskan kepada "di sini dan sekarang". Masa lampau atau masa depan hanya penting bila ada keterkaitan langsung (Corey, 2011, p. 61).

Karena menekankan pada pengalaman konseli sekarang, para terapis atau konselor yang menggunakan pendekatan eksistensial menunjukkan keleluasaan dalam 
menggunakan metode-metode, dan prosedur yang digunakan dapat bervariasi, tidak hanya dari konseli yang satu kepada konseli yang lainnya, tetapi juga dari satu ke lain fase terapi yang dijalani oleh konseli yang sama Meskipun terapi eksistensial bukan merupakan metode tunggal, di kalangan terapis/konselor eksistensial dan humanistik ada kesepakatan menyangkut tugas-tugas dan tanggung jawab terapis berdasarkan tematema atau dalil-dalil umum eksistensial.

Dalil 1: Kesadaran diri. Manusia memiliki kesanggupan untuk menyadari diri yang menjadikan dirinya mampu melampaui situasi sekarang dan membentuk basis bagi aktivitas-aktivitas berpikir dan memilih yang khas manusia. Kesadaran diri membedakan manusia dengan makhluk lainnya. Secara hakikat, semakin tinggi kesadaran diri seseorang, maka ia semakin hidup sebagai pribadi. Meningkatkan kesadaran berarti meningkatkan kesanggupan seseorang untuk mengalami hidup secara penuh sebagai manusia. Peningkatan kesadaran diri yang mencakup kesadaran atas alternatif-alternatif, motivasi-motivasi, faktor-faktor yang membentuk pribadi, dan atas tujuan-tujuan pribadi, adalah segenap tujuan konseling.

Dalil 2: Kebebasan dan tanggung jawab. Kebebasan adalah kesanggupan untuk meletakkan perkembangan di tangan sendiri dan untuk memilih di antara alternatifalternatif. Pendekatan eksistensial meletakkan kebebasan, determinasi diri, keinginan dan putusan pada pusat keberadaan manusia. Tugas konselor adalah membantu konseli dalam menemukan cara-cara penyelesaian masalahnya sendiri secara bebas, tetapi di sisi lain mendorong konseli untuk belajar bertanggung jawab atau menanggung resiko atas keyakinannya terhadap akibat penggunaan kebebasannya tersebut.

Dalil 3: Keterpusatan dari kebutuhan akan orang lain. Individu masing-masing memiliki kebutuhan yang kuat untuk menemukan suatu diri, yakni menemukan identitas pribadi yang unik. Manusia membutuhkan hubungan dengan keberadaan-keberadaan yang lain, dan bergantung pada hubungan dengan orang lain untuk mengoptimalkan kemanusiaannya. Seseorang memiliki kebutuhan untuk menjadi orang yang berarti dalam dunia orang lain, yang mana kehadiran orang lain penting dalam dunianya. Jika ia memperbolehkan orang lain memiliki arti dalam dunianya, maka orang itu mengalami keberhubungan yang bermakna.

Dalil 4: Pencarian makna. Terapi eksistensial menyediakan kerangka konseptual untuk membantu klien dalam usahanya mencari makna hidup. Manusia pada dasarnya selalu dalam pencarian makna dan identitas diri, karena hidup tidak memiliki makna dengan sendirinya, manusialah yang harus menciptakan dan menemukan makna hidup itu. Tugas proses terapeutik adalah menghadapi masalah ketidakbermaknaan dan membantu klien dalam membuat makna dari dunia yang kacau. Manusia yang mengalami keterasingan atau alienasi ketika ia tidak lagi mengenal Tuhan, tidak lagi mengenal sesamanya, bahkan tidak lagi mengenal dirinya sendiri. Situasi ini membuat individu merasa hidupnya menjadi kosong, merasa serba cemas, dan akhirnya terperosok pada situasi psikopatologi. Maka menurut model eksistensial, tujuan psikoterapi adalah menolong individu menjernihkan nilai-nilai hidup, menemukan cara atau jalan hidup yang bermakna.

Dalil 5: Kecemasan sebagai syarat hidup. Kecemasan adalah suatu karakteristik dasar manusia yang mana merupakan sesuatu yang patologis, sebab ia bisa menjadi suatu tenaga motivasional yang kuat untuk pertumbuhan. Manusia mengalami kecemasan dengan meningkatnya kesadaran atas kebebasan dan atas konsekuensi-konsekuensi dari penerimaan ataupun penolakan kebebasannya itu. Berdasarkan dalil ini, maka konseling hadir membantu klien untuk menyadari bahwa belajar menoleransi ketidaktentuan serta 
belajar bagaimana menjalani hidup tanpa sandaran dengan orang lain, belajar dari hidup yang bergantung kepada menjadi pribadi yang lebih otonom.

Dalil 6: Kesadaran atas kematian dan non-ada. Para eksistensialis tidak memandang kematian secara negatif, dan mengungkapkan bahwa hidup memiliki makna karena memiliki keterbatasan waktu. Karena manusia bersifat lahiriah, bagaimanapun, kematian menjadi pendorong untuk menganggap hidup dengan serius.

Dalil 7: Perjuangan untuk aktualisasi diri. Setiap orang memiliki dorongan bawaan untuk menjadi seorang pribadi, yakni mereka memiliki kecenderungan ke arah pengembangan keunikan dan ketunggalan, penemuan identitas pribadi, dan perjuangan demi aktualisasi potensi-potensinya secara penuh. Jika seseorang mampu untuk mengaktualisasikan potensi-potensinya sebagai pribadi, maka ia akan mengalami kepuasan yang paling dalam yang bisa dicapai oleh manusia.

\section{Kompetensi Konselor}

Arah paradigma layanan konseling dekade terakhir berorientasi pada filsafat eksistensialis dan fenomenologis. Paham eksistesialisme dianggap sebagai landasan yang tepat untuk menjawab berbagai persoalan penyelenggaraan layanan konseling. Pendekatan eksistensial-humanistik sebagai pendekatan gelombang ketiga menekankan pada nilai kebebasan manusia, dibanding pendekatan psikoanalisis dan behavioristik yang memandang manusia secara deterministik. Salah satu wujud dari penghormatan terhadap nilai kebebasan nampak pada teori client-centered therapy yang kemudian bergeser menjadi person-centered therapy dari Carl Rogers, dan terapi realitas (reality therapy) oleh William Glasser juga dipengaruhi oleh pendekatan eksistensial.

Konseling dengan pendekatan eksistensial menghargai prinsip-prinsip demokrasi, menekankan proses dialogis, karena kebebasan juga merupakan sebuah pilihan. Berdasarkan prinsip ini, maka konselor bertanggung jawab terhadap sistem nilai yang dianut konseli, selama tidak berlawanan dengan prinsip-prinsip moral. Konselor dituntut untuk berperilaku etis, berperilaku rasional, membangun nilai secara mendalam dan mendorong konseli untuk bertanggung jawab atas pilihannya.

Dialog dalam pandangan Martin Buber (2002) merupakan percakapan antara pribadi dengan pribadi (between man and man), dimana setiap pribadi merupakan subjek bagi yang lainnya. Dalam proses bimbingan, solusi tidak dilimpahkan melainkan ditawarkan. Untuk menjadikan hubungan antara pembimbing dengan siswa sebagai suatu dialog, maka pembimbing tidak bersikap seperti instruktur, konselor harus memberikan kebebasan kepada konseli memilih, tetapi tidak berarti bahwa konseli boleh melakukan apa saja yang disukai. Sementara solusi yang ditawarkan kepada konseli hendaknya menjadi bagian dari pengalaman pribadi pembimbing (konselor) itu sendiri, sehingga konselor ketika berjumpa dengan konseli sebagai pertemuan antara pribadi dengan pribadi. Pada interaksi konseling bisa saja terjadi beragam persoalan, seperti perbedaan atau bahkan pertentangan standar moral yang dimiliki antara konselor-konseli. Keadaan ini menuntut konselor memakai sistem keyakinan (belief system) yang terbentuk untuk memfasilitasi dan membantu konseli. Sistem keyakinan ini dapat hidup dalam diri konselor, jika konselor memahami dan menerapkan prinsip dan hakikat nilai dalam dirinya.

\section{SIMPULAN}

Pada bimbingan dan konseling eksistensial, konselor membantu konseli dalam mengidentifikasi dan mengklarifikasi asumsi mereka tentang dunia. Konseli diajak untuk mendefinisikan dan menayakan tentang cara mereka memandang dan menjadikan 
eksistensi mereka dapat diterima. Konseli mengeksplorasi nilai, keyakinan, dan asumsinya sendiri untuk menentukan persoalan yang dihadapi. Bagi sebagian konseli hal tersebut bukan pekerjaan yang mudah, oleh karena pekerjaan yang mudah, oleh karena itu pada tahap awal dapat dipandu dengan memaparkan permasalahan. Konselor membimbing bagaimana cara untuk bercermin pada eksistensi mereka sendiri dan meneliti peranan mereka dalam hal penciptaan problem mereka dalam hidup. Kemudian, konseli didorong semangatnya untuk lebih dalam lagi meneliti sumber dan otoritas dari sistem nilai mereka. Proses eksplorasi diri ini dapat membawa konseli kepada pemahaman baru berupa restrukturisasi dari nilai dan sikap mereka. Konseli mendapat cita rasa yang lebih baik akan jenis kehidupan macam apa yang dianggap pantas. Konseli mengembangkan gagasan yang jelas tentang proses pemberian nilai internal mereka. Terakhir, proses konseling eksistensial berfokus pada menolong konseli untuk bisa melaksanakan apa yang telah mereka pelajari tentang diri mereka sendiri. Sasaran terapi adalah memungkinkan konseli untuk bisa mencari cara mengaplikasikan nilai hasil penelitian dan internalisasi dengan jalan kongkrit. Biasanya konseli menemukan jalan mereka untuk menggunakan kekuatan itu demi menjalani konsistensi kehidupannya yang memiliki tujuan. Berdasarkan tahapan tersebut, maka dialog adalah kata kunci dalam pendekatan eksistensial. Melalui dialog maka layanan bimbingan dan konseling dapat diaplikasikan secara lebih manusiawi.

\section{REFERENSI}

Binswanger, L. (1963). Being-in-the-world. New York: Basic Books.

Blocher, D.H., (1974). Developmental counseling (2nd Ed.). New York: John Wiley \& Sons.

Buber, M. (1970). I and thou. New York: Scribners.

Buber, M. (2002). Between man and man. London \& New York: Routledge Classic.

Corey, G. (2011). Teori dan praktek konseling dan psikoterapi. Bandung: Refika Aditama.

Feist, J \& Feist, G. (2008). Theories of personality. Yogyakarta: Pustaka Pelajar.

Heidegger, M. (1996). Being and time. New York: State University of New York Press.

Kartadinata, S. (2011). Menguak tabir bimbingan dan konseling sebagai upaya pedagogis. Bandung: UPI Press.

May, R. et al. (1958). Existence: A new dimension in psychiatry and psychology. New York: Basic Books.

Sartre, J. P. (1948). Existentialism and humanism. London: Methuen\&Co.

Sartre, J. P. (1978). Being and nothingness: A phenomenological essay on ontology. New York: Pocket Books.

Sadulloh, U. (2003). Pengantar filsafat pendidikan. Bandung: Alfabeta.

Van Deurzen, E. (2002). Existential counselling and psychotherapy in practice (2 ${ }^{\text {nd }} E$ d.). London: Sage Publications. 